\title{
The enzymatic activity of the VEGFR2 receptor for the biosynthesis of dinucleoside polyphosphates
}

\author{
Vera Jankowski • Anna Schulz • Axel Kretschmer • \\ Harald Mischak • Falko Boehringer • Markus van der Giet • \\ Doreen Janke • Mirjam Schuchardt • Ralf Herwig • \\ Walter Zidek • Joachim Jankowski
}

Received: 9 December 2012 /Revised: 4 March 2013 / Accepted: 25 March 2013 /Published online: 1 May 2013

(C) Springer-Verlag Berlin Heidelberg 2013

\begin{abstract}
The group of dinucleoside polyphosphates encompasses a large number of molecules consisting of two nucleosides which are connected by a phosphate chain of variable length. While the receptors activated by dinucleoside polyphosphates as well as their degradation have been studied in detail, its biosynthesis has not been elucidated so far. Since endothelial cells released the dinucleoside polyphosphate uridine adenosine tetraphosphate $\left(\mathrm{Up}_{4} \mathrm{~A}\right)$, we tested cytosolic proteins of human endothelial cells obtained from dermal vessels elicited for enzymatic activity. When incubated with ADP and UDP, these cells showed increasing concentrations of $\mathrm{Up}_{4} \mathrm{~A}$. The underlying enzyme was isolated by chromatography and the mass spectrometric analysis revealed that the enzymatic activity was caused by the vascular endothelial growth factor receptor 2 (VEGFR2). Since VEGFR2 but
\end{abstract}

Electronic supplementary material The online version of this article (doi:10.1007/s00109-013-1036-y) contains supplementary material, which is available to authorized users.

V. Jankowski $\cdot$ A. Schulz $\cdot$ F. Boehringer $\cdot$ M. van der Giet . D. Janke $\cdot$ M. Schuchardt $\cdot$ W. Zidek $\cdot$ J. Jankowski $(\square)$ Charité-Universitaetsmedizin Berlin, Medizinische Klinik IV, Hindenburgdamm 30,

D-12200 Berlin, Germany

e-mail: Joachim.Jankowski@charite.de

\section{A. Kretschmer}

Bayer Pharma AG, Wuppertal, Germany

H. Mischak

Biomarkers and Systems Medicine, University of Glasgow, Proteomic, Glasgow, UK

R. Herwig

Department Vertebrate Genomics, Max Planck Institute for Molecular Genetics, 14195 Berlin, Germany neither VEGFR1 nor VEGFR3 were capable to synthesise dinucleoside polyphosphates, Tyr-1175 of VEGFR2 is most likely essential for the enzymatic activity of interest. Further, VEGFR2-containing cells like HepG2, THP-1 and RAW264.7 were capable of synthesising dinucleoside polyphosphates. VEGFR2-transfected HEK 293T/17 but not native HEK 293T/17 cells synthesised dinucleoside polyphosphates in vivo too. The simultaneous biosynthesis of dinucleoside polyphosphates could amplify the response to VEGF, since dinucleoside polyphosphates induce cellular growth via P2Y purinergic receptors. Thus the biosynthesis of dinucleoside polyphosphates by VEGFR2 may enhance the proliferative response to VEGF. Given that VEGFR2 is primarily expressed in endothelial cells, the biosynthesis of dinucleoside polyphosphates is mainly located in the vascular system. Since the vasculature is also the main site of action of dinucleoside polyphosphates, activating vascular purinoceptors, blood vessels appear as an autocrine system with respect to dinucleoside polyphosphates. We conclude that VEGFR2 receptor is capable of synthesising dinucleoside polyphosphates. These mediators may modulate the effects of VEGFR2 due to their proliferative effects.

Keywords Enzymatic activity - VEGFR2 receptor . Biosynthesis $\cdot$ Dinucleoside polyphosphates

\section{Introduction}

The group of dinucleoside polyphosphates encompasses a large number of molecules consisting of two nucleosides which are connected by a phosphate chain of variable length, containing between two and seven phosphate moieties. Dinucleoside polyphosphates have been isolated from 
numerous mammalian tissues and were shown to act both as extracellular and intracellular mediators (e.g. [1-3]). $\mathrm{P}_{1}, \mathrm{P}_{4}$ diadenosine tetraphosphate $\left(\mathrm{Ap}_{4} \mathrm{~A}\right)$ was the first diadenosine polyphosphate isolated from mammalian tissue [4]. Some years later, $\mathrm{Ap}_{4} \mathrm{~A}$ was also isolated from human platelets $[5,6]$. Afterwards, diadenosine pentaphosphate $\left(\mathrm{Ap}_{5} \mathrm{~A}\right)$, diadenosine hexaphosphate $\left(\mathrm{Ap}_{6} \mathrm{~A}\right)$ and diadenosine heptaphosphate $\left(\mathrm{Ap}_{7} \mathrm{~A}\right)$ were isolated from human platelets and were characterised as potent vasoconstrictors [7].

The physiological and pathophysiological impact of dinucleoside polyphosphates on, e.g. vascular tone regulation [8], proliferation of VSMC as well as hemodynamic regulation of the renal system was clarified in a large number of studies in recent years (review in, e.g. [3, 9]). The physiological and pathophysiological effects of dinucleoside polyphosphates are mediated by purinergic receptors. The purinergic system and the agonists involved attract increasing interest in cardiovascular research (e.g. [10-12]).

While the receptors activated by dinucleoside polyphosphates as well as their degradation have been studied in detail, the biosynthesis of these compounds has not been elucidated so far. Since endothelial cells released the dinucleoside polyphosphate uridine adenosine tetraphosphate $\left(\mathrm{Up}_{4} \mathrm{~A}\right)$ [13, 14] (review in, e.g. [15]), we tested cytosolic proteins of human endothelial cells obtained from dermal vessels elicited for enzymatic activity in this study. We were able to isolate and identify the enzyme synthesising dinucleoside polyphosphates by this approach.

\section{Methods}

\section{Chemicals}

HPLC water (gradient grade) and acetonitrile (ACN) were from Merck, all other substances from Sigma Aldrich.

\section{Culture of endothelial cells}

Human endothelial cells isolated from dermal microvessels were immortalized to obtain a human microvascular endothelial cell (HMEC-1) line that retains the morphologic, phenotypic and functional characteristics of normal human microvascular endothelial cells [13]. Experiments comparing the phenotypic characteristics of HMEC-1 with primary human dermal microvascular endothelial cells or human umbilical vein endothelial cells revealed that HMEC-1 have features of both small- and large-vessel endothelial cells [13]. On day 0 we placed the cells into $175-\mathrm{cm}^{2}$ cell culture flasks (Nunc Inc., Germany) and stimulated the cells on day 2 at approximately $70 \%$ confluence. Confluent cultures of HMEC-1 showed typical cobblestone appearance and showed the characteristic expression of von Willebrand factor, endothelial NO synthase, VEGF receptor 1 (FLT-1) and the absence of smooth muscle $\alpha$-actin staining. Furthermore, the endothelial cells were incubated in the presence of $\mathrm{Up}_{4} \mathrm{~A}(10 \mu \mathrm{mol} / \mathrm{l})$ and VEGF $(0.2 \mathrm{ng} / \mu \mathrm{l})$ separately and in combination. To investigate the effect of costimulation on the enzymatic activity of VEGFR2, the endothelial cells were cultivated in the presence of recombinant human (rh) Ephrin A4 $(0.4 \mathrm{ng} / \mu \mathrm{l})$.

Stimulation of cultivated endothelial cells

Cell culture flasks of endothelial cells were washed three times with a physiological salt solution. Afterwards, the cell culture flasks of endothelial cells were exposed to shear stress for $10 \mathrm{~min}$ by using a horizontally shaking machine after addition of $10 \mathrm{ml}$ physiologic salt solution. After $10 \mathrm{~min}$, the supernatant was collected and pooled. The supernatant was deproteinized with perchloric acid (final concentration $0.6 \mathrm{~mol} / \mathrm{l}$ ) and centrifuged at 3,500 U/min for $5 \mathrm{~min}$ at $4{ }^{\circ} \mathrm{C}$ and neutralized with $\mathrm{KOH}$ to $\mathrm{pH} 9.5$. The precipitated proteins and the insoluble reaction product $\mathrm{KClO}_{4}$ were removed by centrifugation $\left(3,500 \mathrm{U} / \mathrm{min} ; 4{ }^{\circ} \mathrm{C} ; 5 \mathrm{~min}\right)$. For control reactions, cell culture flasks of endothelial cells were washed three times with $15 \mathrm{ml}$ of a physiological salt solution by avoiding shear stress, salt solution was added extremely slowly. After the washing step, $15 \mathrm{ml}$ physiological salt solution was added to the endothelial cells. Ten minutes later, the supernatant was collected and pooled.

Chromatographic fractionation of the endothelial cytosol

\section{Anion-exchange chromatography}

$\mathrm{K}_{2} \mathrm{HPO}_{4}$ (final concentration $20 \mathrm{mmol} / \mathrm{l}$ ) resolved in water (pH 8) was added to endothelial cytosol. Afterwards, the endothelial cytosol was fractionated by anion-exchanger (column: Uno-Q1, $7 \times 35 \mathrm{~mm}$, Biorad, USA) using $\mathrm{K}_{2} \mathrm{HPO}_{4}(20 \mathrm{mmol} / \mathrm{l})$ in water $(\mathrm{pH} 8)$ as eluent A. The substances retained by the anion-exchanger were eluated at $20 \mathrm{mmol} / 1 \mathrm{~K}_{2} \mathrm{HPO}_{4}$ and $1 \mathrm{~mol} / \mathrm{l} \mathrm{NaCl}$ in water (pH 8) using a step-wise gradient: 0-6 min, $0 \% \mathrm{~B}$; 6-6.1 min, 0-20\% B; 6.1-13.6 min, $20 \% \mathrm{~B}$; $13.5-13.7 \mathrm{~min}, 20-40 \% \mathrm{~B} ; 13.7-$ $21.2 \mathrm{~min}, 40 \% \mathrm{~B} ; 21.2-21.3 \mathrm{~min}, 40-60 \% \mathrm{~B} ; 21.3-$ $28.8 \mathrm{~min}, 60 \% \mathrm{~B} ; 28.8-28.9 \mathrm{~min}, 60-80 \% \mathrm{~B} ; 28.9$ $36.4 \mathrm{~min}, 80 \% \mathrm{~B}$; 36.4-36.5 min, 80-100\% B; 36.5$44.0 \mathrm{~min}, 100 \% \mathrm{~B}$; 44.0-44.1 min, $100-0 \% \mathrm{~B}$; 44.1$53.1 \mathrm{~min}, 80 \% \mathrm{~B}$ (flow rate, $1.5 \mathrm{ml} / \mathrm{min}$; UV absorption wavelength, $280 \mathrm{~nm}$ ).

\section{Cation-exchange chromatography}

The fractions retained by the anion-exchanger were chromatographed using a cation exchanger (column, Uno- 
$\mathrm{S} 1,7 \times 35 \mathrm{~mm}$, Biorad, USA). $\mathrm{KH}_{2} \mathrm{PO}_{4}$ in water $(\mathrm{pH} 3.5)$ was used as eluent $\mathrm{A}$. The substances retained by the cationexchanger were eluated by $20 \mathrm{mmol} / 1 \mathrm{KH}_{2} \mathrm{PO}_{4}$ and $1 \mathrm{~mol} / \mathrm{l}$ $\mathrm{NaCl}$ in water (pH 3.5) using a step-wise gradient: 0-7 min, $0 \% \mathrm{~B}$; 7-7.1 min, 0-50 \% B; 7.1-13.1 min, $50 \% \mathrm{~B}$; 13.1$13.2 \mathrm{~min}, 50-100 \% \mathrm{~B} ; 13.2-19.2 \mathrm{~min}, 100 \% \mathrm{~B} ; 19.2-$ $19.3 \mathrm{~min}, 100-0 \% \mathrm{~B} ; 19.3-29.3 \mathrm{~min}, 0 \% \mathrm{~B}$ (flow rate, $1.0 \mathrm{ml} / \mathrm{min}$; UV absorption wavelength, $280 \mathrm{~nm}$ ).

\section{Size-exclusion chromatography}

The substances not retained by cation-exchange chromatography were fractionated by size-exclusion chromatography. The size-exclusion chromatography gel (Sephacryl S-100 High Resolution; $1000 \times 16$ mm, S100 HR, Pharmacia BioTech, Uppsala, Sweden) was equilibrated with $0.9 \% \mathrm{NaCl}$ in water. The substances not retained by the cation-exchange chromatography were loaded onto the column to elute it with $0.9 \% \mathrm{NaCl}$ in water at a flow rate of $1 \mathrm{ml} / \mathrm{min}$. The elution was monitored with a UV-detector at $280 \mathrm{~nm}$.

\section{Anion-exchange chromatography}

$\mathrm{K}_{2} \mathrm{HPO}_{4}$ (final concentration $20 \mathrm{mmol} / \mathrm{l}$ ) resolved in water $(\mathrm{pH} 8)$ was added to the endothelial cytosol. Afterwards, the cation-exchange fraction with the capacity to synthesise $\mathrm{Up}_{4} \mathrm{~A}$ was fractionated by anion-exchanger using the conditions as described above. Instead of using a step-wise gradient a linear gradient was used for elution the retained substances: 0-8 $\mathrm{min}, 0 \% \mathrm{~B}$; 8-28 $\mathrm{min}, 0-35 \% \mathrm{~B}$; $28-$ $103 \mathrm{~min}, 35-70 \% \mathrm{~B} ; 103-103.2 \mathrm{~min}, 70-100 \% \mathrm{~B} ; 103.2-$ $108.2 \mathrm{~min}, 100 \% \mathrm{~B}$; 108.2-108.4 min, $100-0 \% \mathrm{~B} ; 104.2-$ $114.4 \mathrm{~min}, 0-0 \% \mathrm{~B}$ (flow rate, $1.0 \mathrm{ml} / \mathrm{min}$; UV absorption wavelength, $280 \mathrm{~nm}$ ).

Screening of chromatographic fractions for the enzymatic actviy to biosyntheze $\mathrm{Up}_{4} \mathrm{~A}$

\section{Sample preparation}

One tenth of each fraction volume was desalted using size exclusion gel columns (Mico Bio-Spin P-30 columns; BioRad, USA). Briefly, the gel buffer was exchanged by applying physiologic $\mathrm{NaCl}$ solution. The aliquots of the samples were loaded onto the gel column and centrifuged for $4 \mathrm{~min}$ at $1,000 \times \mathrm{g}$ at room temperature. The filtrates were immobilised and screened for enzymatic activities.

\section{Immobilization of the enzymes}

Endothelial cytosol $(50 \mu \mathrm{l}$; protein concentration $0.5 \mathrm{mg} / \mathrm{ml})$ and $1 / 10$ of the volume of each chromatographic fraction, respectively, were both mixed with $50 \mu \mathrm{NaHCO}_{3}$ and activated $\mathrm{CNBr}-\mathrm{Sepharose} 6 \mathrm{MB}$ beads (Amersham Pharmacia Biotech, Germany). The mixtures were incubated for $1 \mathrm{~h}$ at room temperature. After incubation, the beads were washed three times with double-distilled water. The beads were stored at $4{ }^{\circ} \mathrm{C}$ with sodium azide $(0.05 \%$ final concentration) added.

Incubation of the immobilized enzymes with ADP and UDP as substrates

Two-microliter beads containing the immobilized proteins as well as both types of control beads were transferred into 400-ml reaction vials and washed three times with $10 \mathrm{ml}$ double distilled water to remove the sodium azide.

After each washing step, the liquid was removed using $10-\mu l$ thin tips with a diameter smaller than the diameter of the beads to prevent loss of the beads during washing. Six microlitre of a suspension containing the substrates ADP and UDP $(100 \mu \mathrm{mol} / 1 \mathrm{each})$ was added. Aliquots $(0.5 \mathrm{ml})$ were removed from the reaction mixture after 5,10 and $30 \mathrm{~min}$ for mass spectrometric analysis.

\section{Detection of enzymatic activity by MALDI-MS}

Aliquots from the reaction mixture and from the controls were examined by MALDI-TOF/TOF- MS. For sample preparation, $0.25 \mu \mathrm{l}$ of the reaction mixture was mixed with $0.25 \mu \mathrm{l}$ of matrix solution $(50 \mathrm{mg} / \mathrm{ml} \mathrm{3-hydroxypicolinic}$ acid in water). To this mixture cation-exchange beads (AG $50 \mathrm{~W}-\mathrm{X} 12$, 200-400 mesh, Bio-Rad) equilibrated with $\mathrm{NH}_{4}{ }^{+}$as counterion were added to remove $\mathrm{Na}^{+}$and $\mathrm{K}^{+}$ions. The mixture was gently dried on a 384 format Anchor-Chip target (Bruker-Daltonic, Germany) before analysing with the mass spectrometer.

\section{Matrix-assisted laser desorption/ ionisation mass spectrometry (MALDI-MS) of $U p_{4} A$ contaning fractions}

Mass spectrometric measurements were performed with a Bruker Ultraflex TOF/TOF instrument (Bruker-Daltonics, Germany). The instrument was equipped with a Smart beam $^{\mathrm{TM}}$ laser operating with a repetition rate of 100 $200 \mathrm{~Hz}$. On average, the presented spectra are the sums of 300 single-shot spectra for MS mode, and 1,000 in MS/MS mode. Argon was used as collision-induced dissociation (CID) gas. Mass spectra of positively charged ions were analysed in the reflector mode using delayed ion extraction. Fragment ion spectra were recorded using the LIFT option of the instrument. The calibration constants were determined using standard peptides prepared on positions adjacent to the sample, resulting in an error of $<50 \mathrm{ppm}$ for the recorded mass spectra. The dinucleoside polyphosphate $\mathrm{Ip}_{5} \mathrm{I}$ was added to the sample as internal standard in the case of 
kinetic measurements using MALDI mass spectrometry. Hereby, local differences in the $\mathrm{Up}_{4} \mathrm{~A}$ concentration on the MALDI spot were eliminated [16].

\section{SDS-PAGE electrophoresis}

The protein composition of the protein fractions isolated from endothelial cells were analyzed by SDS-PAGE using the PhastGel gel-system (GE Healthcare, UK) and a gradient gel (10-15\% SDS gradient gel) and PhastGel gel SDSbuffer strips (GE Healthcare, UK). Aliquots of the protein fraction $(20 \mathrm{ng} / \mu \mathrm{l})$ were denatured by adding of SDS to a final concentration of $2.5 \%$ and $\beta$-mercaptroethanol to $5.0 \%$ and heating at $95{ }^{\circ} \mathrm{C}$ for $5 \mathrm{~min}$. SDS-buffer strips contained $10 \mathrm{mmol} / 1 \mathrm{TRIS} / \mathrm{HCl}, 1 \mathrm{mmol} / \mathrm{l}$ EDTA and $0.1 \%$ $(w / v)$ SDS; the $\mathrm{pH}$ was preadjusted to 8.0. We used a voltage of $250 \mathrm{~V}$ and amperage of $10 \mathrm{~mA}$ at $15{ }^{\circ} \mathrm{C}$ for fractionation of the proteins. Following electrophoresis, automated silver staining of SDS gels was performed by using the staining kit "PhastGel SDS media" (GE Healthcare, UK) according to the manufacturer's protocol. Briefly, the samples were fixed by $12.5 \%$ glutardialdehyde and were stained with $0.5 \%$ silver nitrate $\left(\mathrm{AgNO}_{3}\right)$. Formaldehyde $(0.015 \%)$ in $2.5 \%$ sodium carbonate was used as developer and $10 \%$ acetic acid and $10 \%$ glycerol as preserving solution.

\section{Identification of the isolated protein capable of synthesising $U p_{4} A$}

The gel plugs were divided into small pieces and were incubated in $100 \mu \mathrm{l} 50 \mathrm{mmol} / \mathrm{l}$ ammoniumhydrogen carbonate resolved in $\mathrm{H}_{2} \mathrm{O}$ /acetonitrile $(1: 1)$ for $10 \mathrm{~min}$ at $32{ }^{\circ} \mathrm{C}$. After removing the supernatant, the gel plugs were incubated in $100 \mu \mathrm{l} 50 \mathrm{mmol} / \mathrm{l}$ ammoniumhydrogen carbonate in $\mathrm{H}_{2} \mathrm{O}$ for $10 \mathrm{~min}$ at $32{ }^{\circ} \mathrm{C}$. The gel plugs were dehydrated with $50 \mu \mathrm{l}$ $100 \%$ acetronitrile and were dried by using a Speed Vac for $10 \mathrm{~min}$. The gel plugs were incubated with aqueous ammonium bicarbonate $(50 \mathrm{mmol} / \mathrm{l})$ and $0.05 \% \mathrm{w} / \mathrm{v}$ trypsin of $24 \mathrm{~h}$ at $37^{\circ} \mathrm{C}$. The resulting peptides were concentrated and desalted by utilizing the ZipTip $\mathrm{C}_{18}$ (Millipore, USA) technology using water with $0.1 \%$ trifluoroacetic acid (TFA). The elution was done with $60 \%$ acetonitrile in water with $0.1 \%$ TFA. The eluate was spread onto the MALDI target plate (MTP groundsteel $^{\mathrm{TM}}$ 400/384; Bruker-Daltonic, Germany) using alpha-cyano-4-hydroxycinnamic acid $(2.5 \mathrm{mg} / \mathrm{ml})$ as matrix.

\section{Matrix-assisted laser desorption / ionisation mass spectrometry (MALDI-MS)}

After digestion of the protein capable of synthesising $\mathrm{Up}_{4} \mathrm{~A}$, the resulting peptides were resuspended in $10 \mu \mathrm{H}_{2} \mathrm{O} .1 \mu \mathrm{L}$ of each fraction was prepared on a pre-structured MALDI sample support (MTP AnchorChip ${ }^{\text {TM }}$ 400/384, Bruker Daltonics,
Germany) using the $\alpha$-4-hydroxycinnamic acid affinity sample preparation method [17]. The mass-spectrometer and all mass spectrometric conditions were identical as described above. Fragment ion spectra were recorded using the LIFT option of the instrument. The calibration constants were determined using standard peptides prepared on positions adjacent to the sample, resulting in an error of $<100 \mathrm{ppm}$ for the recorded mass spectra. The obtained MS/MS fragment data were compared with data of the NCBInr protein database using Mascot Search Engine, a search engine that uses mass spectrometry data to identify proteins from primary sequence databases (www.matrixscience.com). The identification was focused on probability based molecular weight search (mowse) score of the Mascot algorithm [18].

\section{Enzymactic activity of VEGF receptor 1 and VEGF receptor 3}

A recombinant human vascular endothelial growth factor receptor (VEGFR1; FLT-1), (Sigma-Aldrich, Germany) and a recombinant human vascular endothelial growth factor receptor 3 protein (VEGFR3; FLT-4), (Sigma-Aldrich, Germany) were immobilized to activated $\mathrm{CNBr}-\mathrm{Sepharose}$ $6 \mathrm{MB}$ beads (Amersham Pharmacia Biotech, Germany) and were incubated with ADP and UDP $(100 \mu \mathrm{mol} / \mathrm{l}$ each $)$ at $37^{\circ} \mathrm{C}$ for $12 \mathrm{~h}$. The resulting supernatants were analysed in a time-depend manner by MALDI-TOF/TOF-mass-spectrometry as described above.

Sequence alignment of VEGF receptors VEGFR1, VEGFR2 and VEGFR3

In order to identify similarities and differences of the three protein sequences, we applied a multiple alignment using the CLUSTALW2 algorithm via the UniProt alignment tool [19]. CLUSTALW2 calculates the best global alignment match for the chosen sequences and displays identities, similarities and differences [20]. Similarity of amino acids at each position of the alignment was scored using the Gonnet protein weight matrices, and a gap penalty was computed (gap open penalty $=10$, gap extension penalty $=0.2$ ). Based on this scoring, a hierarchical clustering was computed with the neighbour-joining method.

Characterisation of immobilised, authentic tyrosin kinase receptors for enzymatic activities for $U p_{4} A$ biosynthesis

After the identification of the VEGFR2 protein, two recombinant VEGFR2 proteins (recombinant human vascular endothelial growth factor receptor-2; Prospec-Tany Technogene, Israel; recombinant human VEGFR2 receptor, expressed in mouse NSO cells; Sigma-Aldrich, Germany) were characterised in detail. The recombinant VEGFR2 protein was 
incubated in the presence and absence of the VEGFR2 tyrosine kinase inhibitor $N$-(2,4-difluorophenyl)- $N^{\prime}$-(4-(6,7dimethoxy-4-quinolyloxy)-2-fluorophenyl) urea (Ki8751; Sigma-Aldrich, Germany) and the vascular endothelial growth factor D (VEGF D human, recombinant, expressed in Sf21 cells; Sigma-Aldrich, Germany), respectively.

\section{Cultiviation of raw 264.7, THP-1 and HepG2 cells}

The murine macrophage cell line RAW 264.7 was obtained from the European Collection of Animal Cell Cultures (UK). Cells were cultured in DMEM (4.5 g/L glucose) supplemented with $10 \%$ fetal calf serum (FCS) and $1 \%$ penicillin/streptomycin (Biochrom, Germany). Human liver hepatocellular carcinoma cell line (HepG2) was cultivated in DMEM (4.5 g/l glucose) supplemented with $10 \%$ FCS and $1 \%$ penicillin/streptomycin (Biochrom), too. HepG2 were detached using TrypLE (Invitrogen, Germany). Human acute monocytic leukemia cell line (THP-1) were cultivated in RPMI 1640 (Life Technologies, Germany) supplemented with $10 \% \mathrm{FCS}$ and $1 \%$ penicillin/streptomycin (Biochrom). Cultures were maintained in a humidified incubator in $5 \%$ $\mathrm{CO}_{2}$ at $37^{\circ} \mathrm{C}$.Cells were plated at a concentration of 100,000 cells $/ \mathrm{ml}$.

\section{Transfection of huvec and hmec with siRNA}

Human umbilical vein endothelial cells (HUVEC, pooled donor) and immortalized human microvascular endothelial cells (HMEC-1) were purchased from PromoCell (Germany). The cells were cultivated in antibiotica-free medium supplemented with human growth factors (PromoCell, Germany). Before reaching confluence, cells were detached with trypsin/EDTA, stopped with trypsin neutralization solution (PromoCell, Germany) and seeded in new culture flasks. The cells were cultivated in MCDB-131 (CCPro, Germany) supplemented with $1 \%$ penicillin/streptomycin, $10 \%$ fetal calf serum (FCS), $1 \%$ glutamine, and $0.1 \%$ hydrocortisone (Biochrom AG, Germany) and were passaged every 3 days by scraping, separating and seeding them in new culture flasks. The cells were cultured in a humified atmosphere at $37{ }^{\circ} \mathrm{C}$ and $5 \%$ carbogen dioxide. The cells were serum-starved $48 \mathrm{~h}$ pre-transfection (HMEC: $0 \% \mathrm{FCS}$, HUVEC: $0.5 \%$ supplement mix). $0.5 \times 10^{6}$ (HUVEC) and $1.0 \times 10^{6}$ (HMEC) cells were transfected with predesigned silencer select siRNA against VEGFR2 or negative control siRNA with similar GC level (Life Technologies) using the Amaxa Nucleofector system with cell specific nucleofector solutions (HUVEC nucleofector solution or nucleofector solution Kit R; Lonza, Belgium). Mock-transfected cells were used as a control. Transfection efficacy was verified via real-time PCR.
Detection of VEGFR2 after transfection of huvec and HMEC-1 with siRNA

RNA from cells was isolated using the RNeasy Mini Kit (Qiagen, Germany). RNA was reversely transcribed using the iScript Kit (Biorad, Germany). For semi-quantitative PCR performance, the GoTaq Green Master Mix (Promega, Germany) was used using the following PCR program: $95{ }^{\circ} \mathrm{C}$ for $2 \mathrm{~min}, 95^{\circ} \mathrm{C}$ for $45 \mathrm{~s} ; 60^{\circ} \mathrm{C}$ for $30 \mathrm{~s}, 72{ }^{\circ} \mathrm{C}$ for $45 \mathrm{~s}$ (30 repeats); $72{ }^{\circ} \mathrm{C}$ for $5 \mathrm{~min}$, performed in the Mastercycler Gradient (Eppendorf, Germany). PCR products were separated via electrophoresis on $1.5 \%$ agarose gel stained with ethidium bromide. For quantitative PCR, the SYBR Green mastermix (Biorad, Germany) was used using the following PCR program: $95^{\circ} \mathrm{C}$ for $3 \mathrm{~min}, 95^{\circ} \mathrm{C}$ for $15 \mathrm{~s}$; $60{ }^{\circ} \mathrm{C}$ for $15 \mathrm{~s}, 72^{\circ} \mathrm{C}$ for $1 \mathrm{~min}(39$ repeats), followed by a program for melting curve analysis performed in the CFX96 or CFX384 device (Biorad, Germany). The oligonucleotides were synthesised by Tibmolbiol (Germany) and primer sequences were as follows: VEGFR2 (NM_002253.2) fwd: 5'CTT GCG CGC CGC AGA AAG TC-3', rev: 5'-AGG CAA ACC CAC AGA GGC GG- 3'.

\section{Effect of $U p_{4} A$ on map-kinase, Akt and p38 mitogen- activated protein kinase}

HUVECs (Lonza) were cultured in endothelial cell culture medium (Lonza) consisting of endothelial basal cell growth medium containing (EBM), $2 \%$ FBS and endothelial cell growth supplements. Cells were cultured to $90 \%$ confluence at $37{ }^{\circ} \mathrm{C}$ and $5 \% \mathrm{CO}_{2}$. Following serum starvation in endothelial basal growth medium supplemented with $0.5 \%$ FBS for $24 \mathrm{~h}$, cells were treated with $\mathrm{Up}_{4} \mathrm{~A}$ concentrations as indicated or $20 \mathrm{ng} / \mathrm{mL}$ VEGF (recombinant human VEGF 165, R\&D Systems, 293-VE; Sigma-Aldrich, Germany) for $15 \mathrm{~min}$. Cells were used from passage 2 to passage 4.

Antibodies were from: Phospho ERK1/2 (Thr202/Tyr204, Cell Signaling, 9101, USA) and ERK1/2 (Cell Signaling, 9102); Phospho p38 MAPK (Thr180/Tyr182, BD, 612288 Germany) and p38 MAPK (BD, 612168); Phospho Akt (Ser473, Cell Signaling, 9271, USA) and Akt (Cell Signaling, 9272); anti-mouse HRP-conjugated IgG (GE Healthcare, NXA931 Germany) and anti-rabbit HRP-conjugated IgG (GE Healthcare, NA934, Germany). Total cell lysates in $1.25 \%$ NP40 buffer were prepared as described previously [21]. According to manufacturer's instructions utilizing the Novex gel system (Invitrogen) and 4-12\% gradient gels, equal protein amounts of each sample were subjected to SDS-PAGE and transferred to nitrocellulose membranes (Invitrogen) by electrotransfer. The membranes were blocked in TBS containing $5 \%$ milk and $0.1 \%$ Tween- 20 for $2 \mathrm{~h}$ before overnight incubation at $4{ }^{\circ} \mathrm{C}$ with the appropriate antibody diluted 1:2,000 in TBS containing $0.1 \%$ Tween- 
20. Membranes were washed three times with TBS/0.1\% Tween- 20 before $1 \mathrm{~h}$ incubation with the appropriate secondary HRP conjugated antibody (dilution of 1:5,000). After three washes in TBS $/ 0.1 \%$ Tween- 20 , membranes were developed using the ECL Luminogen-TMA6 reagents (GE Healthcare, Germany) according to the manufacturer's instructions. The G:Box System (Syngene, UK) was used to image proteins on Western blots. Five independent experiments were performed.

\section{Expression of VEGFR2 receptor in the human embryonic} kidney cell line HEK293T

The full-length VEGFR2 kinase insert domain vector (KDR; NCBI GenBank accession no. NM_002253.2) encoding VEGFR2 cDNA under control of the CMV promoter (expression vector pCDNA3, Invitrogen Corp., USA) was transfected into the human embryonic kidney cell line HEK293T/17 (CRL-11268, ATCC, USA) for transient expression of KDR as follows. HEK293T cells were grown up to about $70 \%$ confluency in six $175-\mathrm{cm}^{2}$ tissue culture flasks in OptiMEM medium (Invitrogen Corp.) supplemented with $10 \%(v / v)$ fetal calf serum. The VEGFR2 expression vector was mixed with FuGENE HD transfection reagent according to the protocol provided by the manufacturer (Promega Corp., USA) and diluted in serum-free OptiMEM for transfection of the KDR vector into the cells of three tissue culture flasks. In parallel, the cells in the remaining flasks were transfected under the same conditions using green fluorescence protein expression vector (GFP vector pmaxGFP, Lonza $\mathrm{GmbH}$ ) in order check transfection efficacy as well as to generate a control batch to test for background formation of any dinucleoside polyphosphate activity in HEK293T/17 acceptor cells not carrying the VEGFR2 expression vector. After an incubation period of $48 \mathrm{~h}$, cells were washed with phosphate buffered saline (PBS) and the cells were scraped off and suspended in $1.0 \mathrm{ml}$ PBS resulting in two cell pools, one of which expressing full length VEGFR2. Prior to harvesting, transfection efficacy was checked by frequency of GFP expressing cells which were cultivated in parallel based on photographs made by using an Olympus $1 \times 70$ fluorescence microscope equipped with a NIBA filter. The cells were lyophilized, immobilized and incubated with ADP and UDP as described above.

Stimulation and analysis of cultured native and VEGFR2transfected human embryonic kidney cell line HEK293T/17

We washed cell culture flasks of native and VEGFR2transfected HEK293T/17 three times with a physiological salt solution. To stimulate HEK293T/17 cells we added tumor necrosis factor-alpha [22, 23] (TNF-alpha;
$5 \mathrm{ng} / \mathrm{ml}$ ) or phorbol-myristate-acetate [24, 25] (PMA; $1 \mu \mathrm{mol} / 1)$ in the presence and absence of ADP and UDP $(10 \mu \mathrm{mol} / 1$ each). The cell culture flasks of HEK293T/17 cells were exposed to slight agitation for 15 min by using a horizontally shaking machine. After $15 \mathrm{~min}$, the resulting supernatants were collected and underwent deproteinization with perchloric acid (final concentration $0.6 \mathrm{~mol} / \mathrm{l}$ ), centrifugation at $3,500 \mathrm{U} / \mathrm{min}$ for $5 \mathrm{~min}$ at $4{ }^{\circ} \mathrm{C}$ and neutralization with $\mathrm{KOH}$ to $\mathrm{pH}$ 9.5. We removed the precipitated proteins and the insoluble reaction product $\mathrm{KClO}_{4}$ by centrifugation (3,500 U/min; $\left.4{ }^{\circ} \mathrm{C} ; 5 \mathrm{~min}\right)$.

We added triethylammonium acetate $(40 \mathrm{mmol} / \mathrm{l}$ final concentration) was added to the supernatants and titrated $\mathrm{pH}$ to 6.5. Next, we used a $\mathrm{C} 18$ reversed-phase column (Chromolith $^{\text {TM }}$ Performance RP-18e 100-4.6, Merck, Germany) to concentrate the supernatant of native and transfected HEK293T/17 cells. We removed non-binding substances with triethylammonium acetate. Then we eluted binding substances stepwise with $20 \% \mathrm{ACN}$ in water at a flow rate of $2.0 \mathrm{ml} / \mathrm{min}$. We monitored the elution by measuring the UV absorption at $254 \mathrm{~nm}$. Last, we froze the eluate at $-80^{\circ} \mathrm{C}$ and lyophilized it. We examined the lyophilized fractions from the reversed phase chromatography by MALDI-TOF/TOF mass-spectrometry using the conditions as described above.

\section{Results}

Isolation of the dinucleoside polpyhosphate synthesising enzyme

The cytosolic, immobilised proteins obtained from human endothelial cells showed the biosynthesis of $\mathrm{Up}_{4} \mathrm{~A}$ when incubated with ADP and UDP. To isolate the underlying enzyme, first, the cytosolic proteins were separated by anionexchange chromatography (Fig. 1a). Aliquots of each anionexchange chromatographic fraction were immobilised for further incubation with ADP and UDP. The reaction products were analysed by matrix-assisted laser desorption/ionisation (MALDI) time-of-flight (TOF)/TOF-mass spectrometry. One fraction of the anion-exchange chromatography eluting by $60 \mathrm{mmol} / \mathrm{l}$ aqueous $\mathrm{NaCl}$ solution had the capacity for synthesising dinucleoside polyphosphates. The corresponding fraction is labelled by an arrow in Fig. 1a. Figure 1b demonstrates a corresponding MALDI-TOF/TOF-mass-spectrum of synthesised $\mathrm{Up}_{4} \mathrm{~A}$. Next, this fraction was fractionated by cation-exchange chromatography (Fig. 1c). The resulting fractions were screened again for the enzymatic activity of interest. The fraction not retained by the cation-exchanger (labelled by an arrow in Fig. 1c) had the capacity of synthesising $\mathrm{Up}_{4} \mathrm{~A}$ from UDP and ADP. This fraction was further fractionated by 
size-exclusion (Fig. 1d) and anion-exchange chromatography using a linear gradient (Fig. 1e).

Isolation of the dinucleoside polpyhosphate synthesising enzyme

Since the heterogeneity of the cytosolic proteins was significantly reduced by this column-chromatographic steps (Fig. 1f; band a vs. band c), we fractioned the fraction of interest by native gel-electrophoresis. The fraction eluting at 93 min showed the enzymatic activity of interest. Following SDS-PAGE fractionation, we further analysed this fraction after tryptic degradation via MALDI-TOF/TOF-mass spectrometry (Fig. 2a) and
A

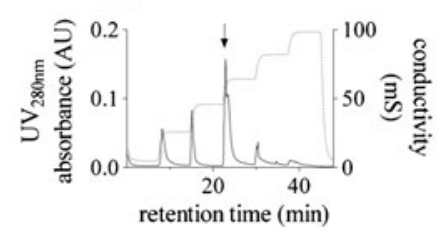

C

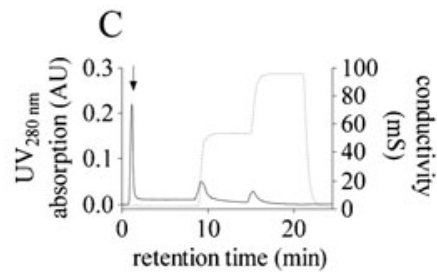

E

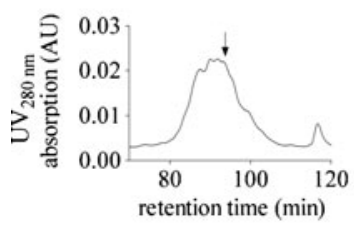

B

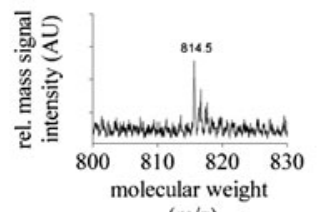

D

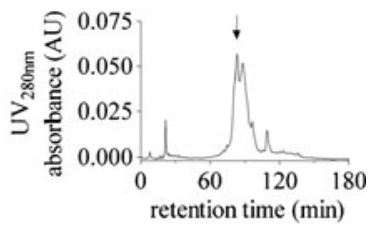

$\mathrm{F}$

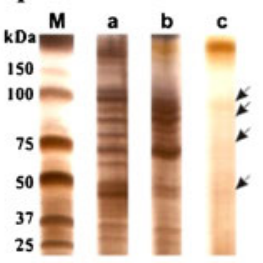

Fig. 1 a Anion-exchange-chromatography of cytosolic proteins of endothelial cells. The fraction labelled by an arrow was capable of synthesising $\mathrm{Up}_{4} \mathrm{~A}$ during incubation with ADP and UDP $(100 \mu \mathrm{mol} / 1$ each). b MALDI-TOF-TOF-mass spectrum of the cation-exchange chromatographic fraction labelled in a. The molecular mass of 815.5 Da corresponds to the molecular mass of $\mathrm{Up}_{4} \mathrm{~A}\left(\mathrm{M}+\mathrm{H}^{+}\right)$. c. Cation-exchange chromatogram of the fraction labelled in $\mathbf{a}$. The fraction labelled by an arrow was capable of synthesising $\mathrm{Up}_{4} \mathrm{~A}$ during incubation with ADP and UDP $(100 \mu \mathrm{mol} / 1$ each $)$. d Size-exclusion chromatography of the fraction not retained by the cation-exchanger labelled by an arrow in c. The fraction labelled by an arrow was capable of synthesising $\mathrm{Up}_{4} \mathrm{~A}$ during incubation with ADP and UDP $(100 \mu \mathrm{mol} / 1$ each). e Linear gradient anion-exchange chromatography of size-exclusion chromatographic fraction eluting at $82 \mathrm{~min}(\mathbf{d})$. The fraction labelled by an arrow was capable of synthesising $\mathrm{Up}_{4} \mathrm{~A}$ during incubation with ADP and UDP (100 $\mu \mathrm{mol} / \mathrm{l}$ each). f SDS-PAGE of endothelial cytosolic proteins $\mathbf{a}$ after lysis of the cells, $\mathbf{b}$ after subsequent anion-exchange-chromatography a and $\mathbf{c}$ after anion-change chromatographic fraction (e) capable of synthesising $\mathrm{Up}_{4} \mathrm{~A}$. The labelled bands were caused by a protein capable of synthesising $\mathrm{Up}_{4} \mathrm{~A}$ after incubation with ADP and UDP $(100 \mu \mathrm{mol} / \mathrm{l}$ each $)$

identified the VEGFR2 protein using the probability based molecular weight search (mowse) score of the Mascot algorithm in this fraction (Fig. 2b).

Verification of enzymatic activity

To verify whether the detected enzymatic activity was attributable to the VEGFR2 receptor protein, we incubated a commercially available VEGFR2 protein after immobilisation with ADP and UDP. After an incubation period exceeding $10 \mathrm{~min}$, we were able to detect a significant amount of $\mathrm{Up}_{4} \mathrm{~A}$ in the supernatant. Figure $2 \mathrm{c}$ demonstrates the MALDITOF/TOF fragmentation mass spectrum of the enzymatically synthesised $\mathrm{Up}_{4} \mathrm{~A}$ in the reaction mixture. Each signal was attributable to a fragment of $\mathrm{Up}_{4} \mathrm{~A}$ as shown in Table 1 ,

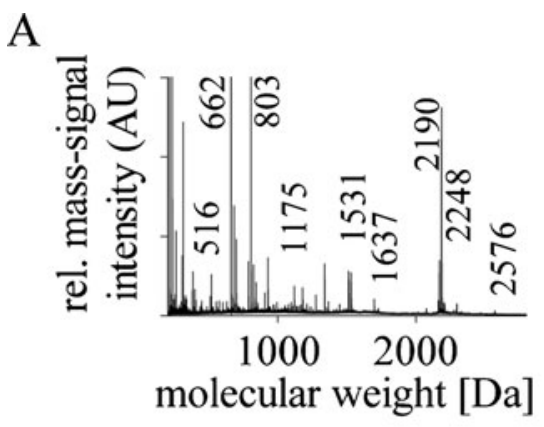

B
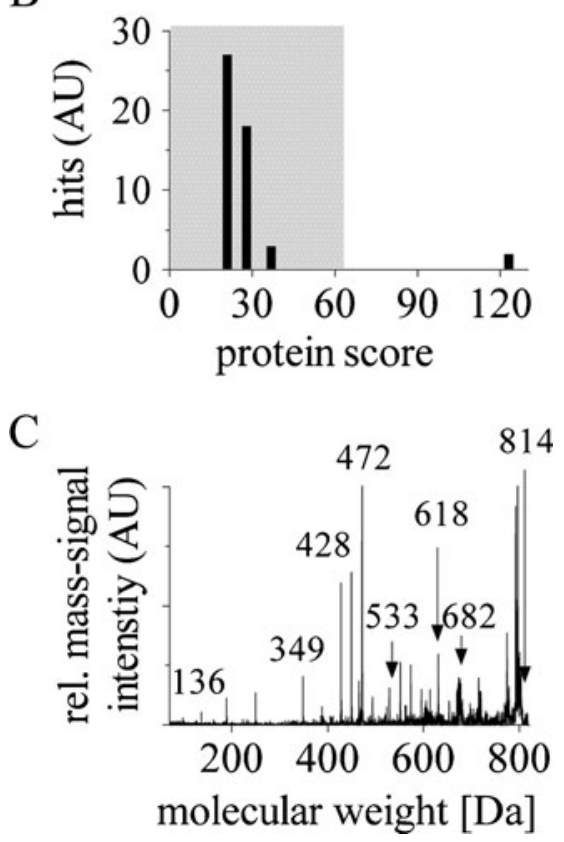

Fig. 2 a MALDI-TOF/TOF-fragmentation mass-spectrum of the isolated protein with the enzymatic capacity to synthesise $\mathrm{Up}_{4} \mathrm{~A}$ from ADP and UDP (100 $\mu \mathrm{mol} / 1$ each). b Probability based molecular weight search (MOWSE) score of Mascot-Search using the MS/MS data shown in Fig. 2a. c MALDI-TOF/TOF-fragmentation mass-spectrum of $\mathrm{Up}_{4} \mathrm{~A}$ synthesised by VEGFR2 receptor after incubation of ADP and UDP (100 $\mu \mathrm{mol} / 1 \mathrm{each})$. 
Table 1 Molecular masses of $\mathrm{Up}_{4} \mathrm{~A}$ fragments obtained by MALDI-TOF/TOF-mass spectrometry. The mass signals were obtained from MS/MS-spectrum given in Fig. 2c. The middle column: fragment masses measured by MALDI-TOF/TOFmass spectrometry; right column: fragment masses expected theoretically from their respective structures (left column)

$M^{+}$protonated parent ion, $U^{\prime}$ uracil, $A$ adenosine, $U$ uridine; $p$ phosphate group, e.g. $A p_{3}$ ATP; w/o without

\begin{tabular}{|c|c|c|}
\hline $\begin{array}{l}\text { Interpretation of the MALDI-TOF/TOF } \\
\text { mass signals }[\mathrm{M}+\mathrm{H}]^{+}\end{array}$ & $\begin{array}{l}\text { MALDI-TOF/TOF mass } \\
\text { signal }[\mathrm{m} / \mathrm{z}] \text { measured }\end{array}$ & $\begin{array}{l}\text { MALDI-TOF/TOF mass } \\
\text { signal }[\mathrm{m} / \mathrm{z}] \text { calculated }\end{array}$ \\
\hline $\mathrm{Ap}_{1} \mathrm{w} / \mathrm{o} \mathrm{H} \mathrm{H}_{2} \mathrm{O}$ & 330.9 & 330.1 \\
\hline $\mathrm{Ap}_{2} \mathrm{w} / \mathrm{o} \mathrm{H} \mathrm{H}_{2} \mathrm{O}$ & 409.9 & 410.0 \\
\hline $\mathrm{Ap}_{2}$ & 427.9 & 428.0 \\
\hline $\mathrm{Up}_{3}$ w/o $2 \mathrm{H}_{2} \mathrm{O}$ & 450.0 & 448.1 \\
\hline $\mathrm{Up}_{3}$ w/o $\mathrm{H}_{2} \mathrm{O}$ & 465.9 & 466.2 \\
\hline $\mathrm{Ap}_{3} \mathrm{w} / \mathrm{o} \mathrm{H} \mathrm{H}_{2} \mathrm{O}$ & 489.9 & 490.0 \\
\hline $\mathrm{Mw} / \mathrm{o} \mathrm{Up}_{1}$ & 488.0 & 488.9 \\
\hline $\mathrm{M}$ w/o $\mathrm{U}^{\prime}+2 \mathrm{H}_{2} \mathrm{O}$ & 717.9 & 719.0 \\
\hline $\mathrm{Mw} / \mathrm{o} \mathrm{U}+\mathrm{H}_{2} \mathrm{O}$ & 551.5 & 552.0 \\
\hline $\mathrm{Up}_{4}+3 \mathrm{H}_{2} \mathrm{O}$ & 617.9 & 618.1 \\
\hline Not interpreted & 629.0 & \\
\hline $\mathrm{M}$ w/o $\mathrm{U}^{\prime}$ and $\mathrm{w} / \mathrm{o} \mathrm{H}_{2} \mathrm{O}$ & 682.9 & 682.9 \\
\hline Not interpreted & 722.9 & \\
\hline M & 814.0 & 814.1 \\
\hline
\end{tabular}

suggesting that $\mathrm{Up}_{4} \mathrm{~A}$ is a synthesis product of the VEGFR2 protein.

Characterisation of enzymatic activities of the VEGFR2

To examine whether the enzymatic activity for the synthesis of dinucleoside polyphosphates is specific for the VEGFR2 receptor or this activity is a general mechanism for VEGF receptors, we immobilised commercially available VEGFR1, VEGFR2 and VEGFR3 proteins and incubated these proteins with ADP and UDP. Dinucleoside polyphosphates were exclusively formed by reaction mixtures containing VEGFR2. In contrast, reaction mixtures containing either VEGFR1 or VEGFR3 did not contain dinucleoside polyphosphates, even after prolonged incubation periods up to two hours (Electronic supplementary material (ESM) Supplementary Fig. 2). Therefore, the enzymatic activity for the synthesis of dinucleoside polyphosphates is obviously specific for the VEGFR2 receptor.

Figure 3 a demonstrates the time-dependent $\mathrm{Up}_{4} \mathrm{~A}$ biosynthesis through the VEGFR2 protein in the reaction mixture. The $\mathrm{Up}_{4} \mathrm{~A}$ production by the VEGFR2 receptor protein is not directly caused by its tyrosine kinase activity since the selective VEGFR2 tyrosine kinase inhibitor Ki8751 had no effect on this activity (Fig. 3b). The inhibitory properties of Ki8751 on the tyrosine kinase activity of the VEGFR2 protein was validated by using random copolymer poly(Glu,Tyr) as a positive control (ESM Supplementary Fig. 3).

Verfication of the phosphorylation activity of VEGFR2

To verify the specificity of the enzymatic activity of the VEGFR2 protein, we incubated VEGFR2 with the tyrosinefree peptide Kemptide (Leu-Arg-Arg-Ala-Ser-Leu-Gly) as negative control and poly-Glu,Tyr as positive control. While the VEGFR2 protein did not phosphorylate Kemptide (data not shown), incubation of the VEGFR2 protein with poly-Glu, Tyr demonstrates the tyrosine kinase activity (Fig. 3c). While rhEphrin-A4 has a slight increasing effect on the proliferation rate of HMEC cells (15.7 $\pm 2.3 \%$ above control), ephrin-A4 caused an 2.1-fold increase of the enzymatic activity for $\mathrm{Up}_{4} \mathrm{~A}$ synthesis of the immobilised HMEC $(0.69 \pm 0.06$ vs. $0.33 \pm$ 0.09 (AU); $p<0.05 ; N=3$ each). In cultivated EC, presence of rhEphrin-A4 cause an strong increased of the $\mathrm{Up}_{4} \mathrm{~A}$ synthesis rate and secretion rate compared to control conditions in the absence of rhEphrin-A4 ( $0.0933 \pm 0.0328$ vs. $0.0014 \pm 0.0003$ (AU); $p<0.05 ; N=3$ each).

Specificity of the dinucleoside polyphosphate synthesising activity of VEGFR2

The specificity of the VEGFR2 protein is also reflected by the fact that the VEGFR2 protein synthesises (Fig. 3a) but does not metabolise $\mathrm{Up}_{4} \mathrm{~A}$ (Fig. 3d). However, the enzymatic activity of the VEGFR2 protein for dinucleoside polyphosphate formation is obviously not restricted to a small number or selected of mononucleoside polyphosphates (Table 2). These findings show that VEGFR2 is capable of synthesising all known types of dinucleoside polyphosphates (Table 2).

Furthermore, the question arose whether the binding of VEGF at the VEGFR2 receptor protein had an effect on this enzymatic activity of the receptor. The presence of VEGF has no significant effect on the enzymatic activity of interest (Fig. 3e). The $\mathrm{Up}_{4} \mathrm{~A}$-synthesising activity is not a specific activity of endothelial cells, since other VEGFR2 expressing cells like HEPG2 [26, 27], THP-1 [28] and RAW264.7 [29] cells are capable to synthesise $\mathrm{Up}_{4} \mathrm{~A}$ by incubation with ADP and UDP, too (Fig. 3f). 
A

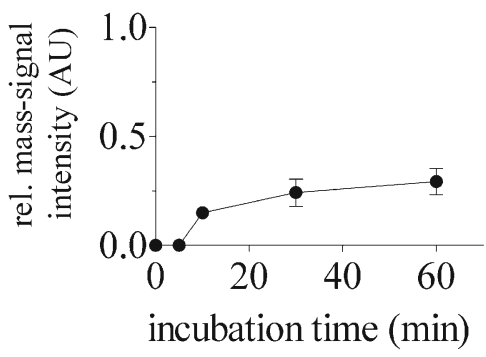

$\mathrm{C}$

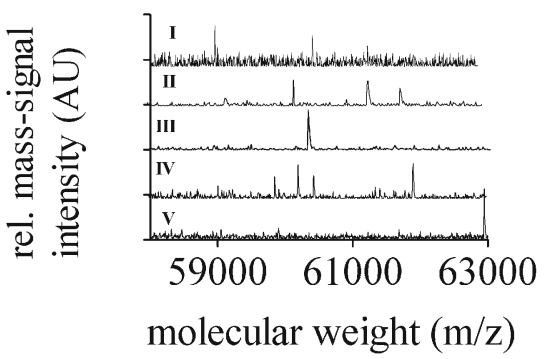

E

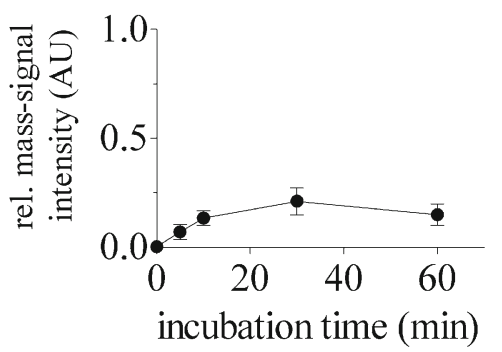

Fig. 3 a. Time dependence of enzymatic $\mathrm{Up}_{4} \mathrm{~A}$ production by immobilised, recombinant VEGFR2 protein incubated with ADP and UDP $(100 \mu \mathrm{mol} / 1$ each; $\mathrm{n}=8)$. b Time dependence of enzymatic $\mathrm{Up}_{4} \mathrm{~A}$ production by immobilised, recombinant VEGFR2 protein incubated with ADP and UDP $(100 \mu \mathrm{mol} / \mathrm{l}$ each $)$ in presence of the tyrosine kinase inhibitor Ki8751(200 nmol/1) $(\mathrm{n}=5)$. c Representative MALDImass spectra of poly-Glu,Tyr before (I) and after 5-min (II), 10-min (III), 30-min (IV) and 60-min (V) incubation with immobilised, recombinant VEGFR2 protein. The spectra demonstrate an characteristic enzymatic activity of immobilised, recombinant VEGFR2 protein

\section{Transfection of HMEC-1 cells with siRNA}

For validation of the findings, HMEC-1 were transfected with siRNA directed against the VEGFR2. The electroporationbased transfection was controlled by real-time PCR and Western Blot. After immobilisation, the transfected cells were incubated with ADP and UDP. The $\mathrm{Up}_{4} \mathrm{~A}$ synthesis rates of cells transiently lacking the VEGFR2 were significantly reduced compared to untransfected cells (Fig. 4a). After transient transfection with siRNA against VEGFR2, the $\mathrm{Up}_{4} \mathrm{~A}$ synthesis rate significantly decreased compared to mocktransfected cells (Fig. 4a), confirming the assumption of dinucleoside polyphosphate synthesis by VEGFR2. After
$\mathrm{B}$

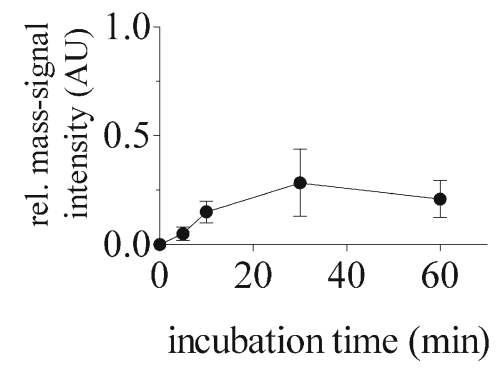

$\mathrm{D}$

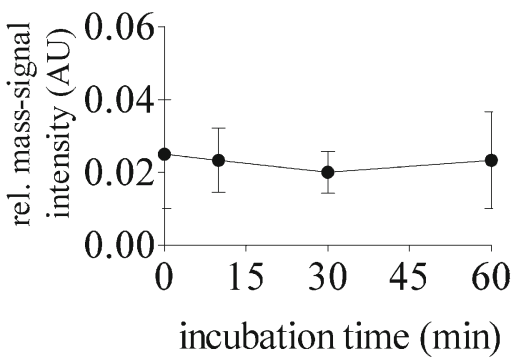

$\mathrm{F}$

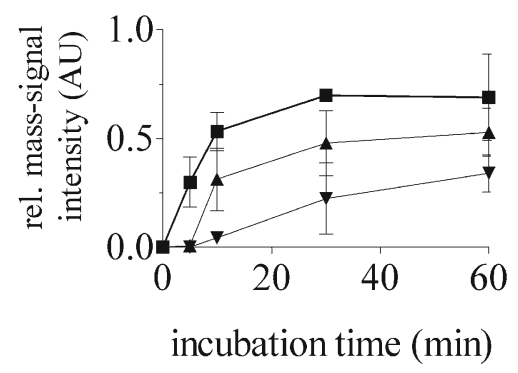

by the enzymatic phosphorylation of the poly-Glu,Tyr. d Incubation of $\mathrm{Up}_{4} \mathrm{~A}$ with immobilised, recombinant VEGFR2 protein. The results demonstrated no metabolic activity of the VEGFR2 protein for metabolism of $\mathrm{Up}_{4} \mathrm{~A}$. e Time dependence of enzymatic $\mathrm{Up}_{4} \mathrm{~A}$ production by immobilised, recombinant VEGFR2 protein incubated with ADP and UDP $(100 \mu \mathrm{mol} / 1 \mathrm{each})$ in presence of VEGF $(250 \mathrm{nmol} / \mathrm{l})(n=11)$. $\mathbf{f}$ Time-dependence of enzymatic $\mathrm{Up}_{4} \mathrm{~A}$ production by cultivated HepG2 (solid square), THP-1 (up-pointing filled triangle) and RAW (downpointing filled triangle) cells by incubation of ADP and UDP $(100 \mu \mathrm{mol} / 1$ each; $\mathrm{n}=3)$

transient transfection with siRNA against VEGFR2, cultivated HMECs were not capable to release $\mathrm{Up}_{4} \mathrm{~A}$ into the supernatant after stimulation by shear stress. The use of HUVEC cells instead of HMEC cells leads to comparable results (data not shown).

Modulation of VEGFR2-induced pathways

Given that VEGFR2 mediates both the VEGF actions and dinucleoside polyphosphate synthesis, the question arose whether a dinucleoside polyphosphate such as $\mathrm{Up}_{4} \mathrm{~A}$ modulates VEGFR2 induced pathways. $\mathrm{Up}_{4} \mathrm{~A}$ modulates the phosphorylation of the mitogen-activated 
Table 2 Dinucleoside polyphosphates detected by MALDI-TOF/ TOF-mass spectrometry after incubation of mononucleoside polyphosphates in the presence of immobilised VEGFR2 protein

\begin{tabular}{ll}
\hline Mononucleoside & Detected dinucleoside \\
polyphosphates incubated & polyphosphates detected by \\
with VEGFR2 & MALDI-TOF/TOF-mass \\
& spectrometry \\
\hline
\end{tabular}

\section{AMP}

$\mathrm{AMP}+\mathrm{GMP}$

$\mathrm{AMP}+\mathrm{UDP}$

ADP

$\mathrm{ADP}+\mathrm{GMP}$

$\mathrm{ADP}+\mathrm{UDP}$

ATP

$\mathrm{ATP}+\mathrm{GMP}$

ATP+UDP

protein kinase p42/p44 (MAPkinase) (Fig. 4b), but has neither an effect on endothelial p38-alpha MAPK nor protein kinase B (AKT) (data not shown). Both VEGF and $\mathrm{Up}_{4} \mathrm{~A}$ caused a significant increase in the proliferation rate of cultivated HMEC (VEGF, 13.3 $\pm 2.5 ; \mathrm{Up}_{4} \mathrm{~A}$, $9.4 \pm 1.8$ ), which was enhanced in case of a combined application of the stimulants $(14.9 \pm 2.9)$ (each percentage above control).

Transfection of HEK293t/17 cells with VEGFR2 expression vector

Next, we treated HEK293T/17 cells with a VEGFR2 expression vector. The efficacy of transfection was estimated based on a transient transfection conducted in parallel using the expression vector pmaxGFP for green fluorescent protein expression and subsequent counting of fluorescently labeled cells by fluorescence microscopy. After $48 \mathrm{~h}$, approximately $60 \%$ of cells expressed GFP (Fig. 4c). While native HEK-293T/17 cells were not able to synthesise $\mathrm{Up}_{4} \mathrm{~A}$ from UDP and ADP, VEGFR2transfected immobilized cells significantly synthesised a high amount of $\mathrm{Up}_{4} \mathrm{~A}$ after adding UDP and ADP (Fig. 4d).

Finally, we studied whether VEGFR2-transfected HEK293/17 are capable to synthesise and to release dinucleoside polyphosphates after stimulation in vivo, too. Tumor necrosis factor-alpha (TNF-alpha) [22, 23] or PMA $[24,25]$ stimulated the release of $\mathrm{Up}_{4} \mathrm{~A}$ from VEGFR2transfected HEK 293/17, but not from native HEK 293/17 cells (Fig. 4e). The amount of $\mathrm{Up}_{4} \mathrm{~A}$ in the supernatant of stimulated VEGFR2-transfected HEK 293/17 was increased in the presence of ADP und UDP (Fig. 4e). These results show that VEGFR2 is essential for dinucleoside polyphosphate synthesis in vivo.

\section{Discussion}

Enzymatic activity of VEGF2 for synthesis of dinucleoside polyphosphates

Endothelial cells showed increasing concentrations of dinucleoside polyphosphate like $\mathrm{Up}_{4} \mathrm{~A}$ when incubated with ADP and UDP. We were able to isolate the underlying enzyme to homogeneity by ion-exchange- and size-exclusion column chromatography, as well as both native and SDS gel chromatography to homogeneity. MALDI-TOF/TOF mass spectrometric analysis revealed that the enzymatic activity was caused by the vascular endothelial growth factor receptor 2 (VEGFR2). VEGFR2 is a receptor tyrosine kinase and plays an important role in angiogenesis (review in, e.g. [30]).

The biosynthesis of dinucleoside polyphosphates did not decrease either in the presence of the selective VEGFR2tyrosine kinase inhibitor Ki8751 nor in the presence of VEGF. Beside endothelial cells, further VEGFR2-containing cells like HepG2, THP-1 and RAW264.7 were capable of synthesising dinucleoside polyphosphates. VEGFR2transfected HEK 293T/17 but not native HEK 293T/17 cells synthesised and released dinucleoside polyphosphates after stimulation in vivo too. The dinucleoside polyphosphate amount was increased in the presence of the mononucleoside polyphosphates ADP and UDP.

VEGFR2 domains responsible for synthesis of dinucleoside polyphosphates

After identification, the question arose which VEGFR2 domains are responsible for the biosynthesis of dinucleoside polyphosphates. The experiments with VEGF show that the binding of this ligand does not affect dinucleoside polyphosphate biosynthesis. Therefore, dinucleoside polyphosphate biosynthesis may be affected by the transmembrane or the juxtamembrane domain. Moreover, it may be assumed that mononucleotide phosphorylation is performed analogous to tyrosine phosphorylation. As a consequence, the same domain which is responsible for tyrosine autophosphorylation may also synthesise dinucleoside polyphosphates. To further investigate the domain responsible for dinucleoside polyphosphate synthesis, we tested the various receptor subtypes VEGFR1-3 for their ability to synthesise dinucleoside polyphosphates.

VEGFR1, VEGFR2- and VEGF3 amino acid sequences we computed a multiple alignment using the CLUSTALW algorithm via the UniProt alignment tool [19]. Several functional domains are shared by all 3 VEGFR subtypes, like carry sites for proton acceptor (VEGFR1 at 1072, VEGFR2 at 1028 and VEGFR3 at 1037) and ATP binding (VEGFR1 at 861, VEGFR2 at 868 and VEGFR3 at 879) in their protein-kinase domain. In addition, VGFR2 carries an additional, specific site 
Fig. 4 a Detection of $\mathrm{Up}_{4} \mathrm{~A}$ synthesising activity of HMEC1 mock transfected (circle) and (down-pointing filled triangle) transient transfected with siRNA against VEGFR2, or (up-pointing filled triangle) with negative control siRNA by incubation of ADP and UDP (100 $\mu \mathrm{mol} / 1$ each). b Quantification of $\mathrm{Up}_{4} \mathrm{~A}$ effect on $\mathrm{p} 42 / \mathrm{p} 44 \mathrm{MAPK}$

phosphorylation measured

Western blot analysis. c

Transient transfection of HEK-

293T cells with green

fluorescence protein expression vector as control vector after 24-h (upper panel) and 48-h (lower panel) incubation. d Detection of $\mathrm{Up}_{4} \mathrm{~A}$-synthesising activity of native and VEGFR2transfected HEK-293T cells in the presence of ADP and UDP (100 $\mu \mathrm{mol} / 1$ each). e Quantification of $\mathrm{Up}_{4} \mathrm{~A}$ in supernatants of native HEK 293T/17 cells and VEGFR2transfected HEK 293T/17 cells after stimulating with tumor necrosis factor-alpha (TNFalpha) or phorbol-myristateacetate (PMA) and after stimulation with TNF-alpha or phorbol-myristate-acetate in absence and presence of ADP und UDP (100 $\mu \mathrm{mol} / \mathrm{l}$ each)
A

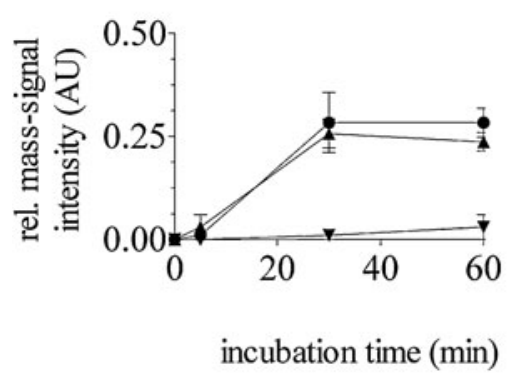

C
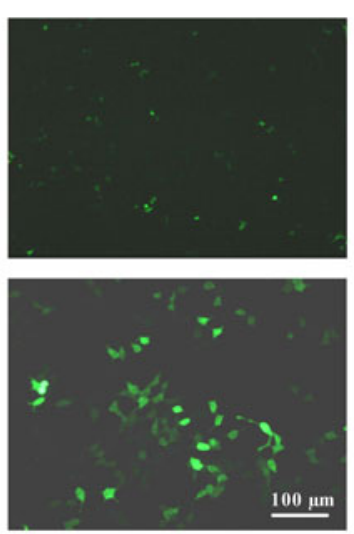

E

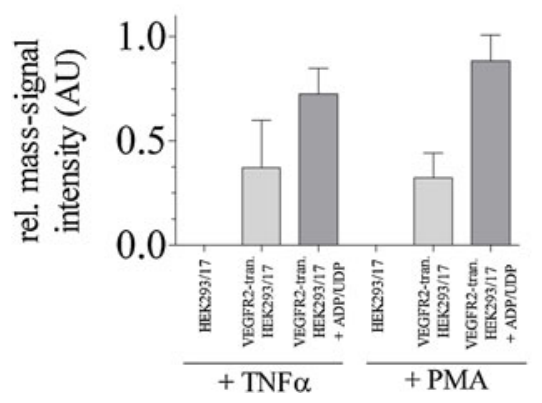

B

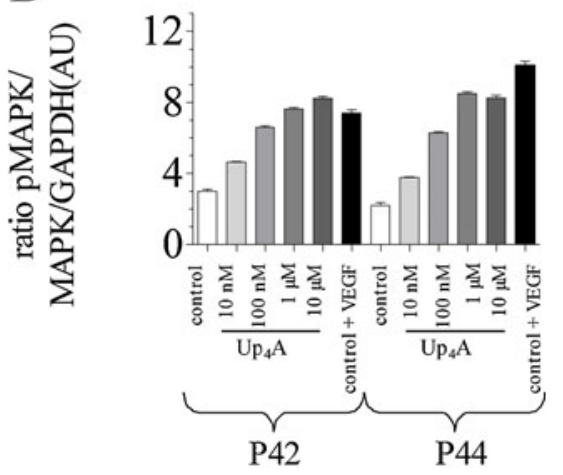

D

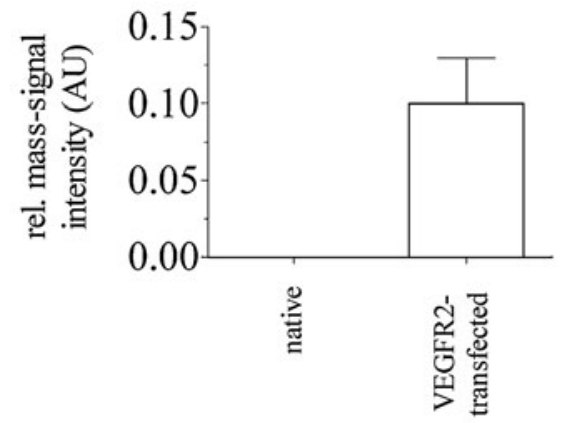

at tyrosine 1175 , which has been identified previously as a prominent interaction site and which is not present in the other VEGFR subtypes. The result of the alignment is illustrated in ESM Supplementary Fig. 1. Tyr-1175 of VEGFR2 is most likely essential for the enzymatic activity for synthesis of dinucleoside polyphosphates.

The VEGFR2-specific site at Tyr-1175 has been reported before as a phosphorylation site which is important for interaction with PLCG1 [31] and SHB [32]. Holmqvist et al. have performed co-immunoprecipitation experiments and detected an interaction between SHB and VEGFR2 in human telomerase-immortalized microvascular endothelial cells that was important for VEGF signalling in endothelial cells and regulated VEGF-induced formation of focal adhesion and cell migration. In addition, Sase et al. examined the signal transduction pathway downstream of VEGFR2 for endothelial differentiation using an in vitro differentiation system of mouse embryonic stem-cell-derived VEGFR2 ${ }^{+}$cells and found an interaction of VEGFR2 to PLCG1, an inducer of endothelial specification, via Tyr-1175 phosphorylation [31]. In contrast, this interaction was not detectable with VEGFR-3, supporting a unique function of VEGFR2 in endothelial differentiation from vascular progenitors. Therefore, it can be assumed that this is also the functional domain mediating the biosynthesis of dinucleoside polyphosphates.

Impact of dinucleoside polyphosphates on VEGFR2 actions

Given that VEGFR2 is one of the enzymes responsible for the biosynthesis of dinucleoside polyphosphates, the question 
arises whether dinucleoside polyphosphates might play a role in the context of VEGFR2 actions. Since VEGFR2 is involved in the regulation of endothelial proliferation and angiogenesis, the effect of $\mathrm{Up}_{4} \mathrm{~A}$ as a characteristic dinucleoside polyphosphate on $\mathrm{p} 42 / \mathrm{p} 44$ MAPK was investigated. The activation level of p42/p44 MAPK increases steadily dependent on the applied $\mathrm{Up}_{4} \mathrm{~A}$ concentration. The stimulation of HUVECs with $10 \mu \mathrm{mol} / 1 \mathrm{Up}_{4} \mathrm{~A}$ results in an equivalent phosphorylation level of the p42/p44 MAPK compared to $20 \mathrm{ng} / \mathrm{ml}$ VEGF. The biosynthesis of dinucleoside polyphosphates by VEGFR2 may obviously stimulate the proliferative response of HUVEC to VEGF. Since dinucleoside polyphosphates caused proliferative effects via $\mathrm{P} 2 \mathrm{Y}$ purinergic receptors [3, 33], the simultaneous biosynthesis of dinucleoside polyphosphates could amplify the response to VEGF, since dinucleoside polyphosphates are known to induce cellular growth via $\mathrm{P} 2 \mathrm{Y}$ purinergic receptors. Thus the biosynthesis of dinucleoside polyphosphates by VEGFR2 may enhance the proliferative response to VEGF.

Given that VEGFR2 is primarily expressed in endothelial cells, the biosynthesis of dinucleoside polyphosphates is mainly located in the vascular system. Since the vasculature is also the main site of action of dinucleoside polyphosphates, activating vascular purinoceptors, blood vessels appear as an autocrine system with respect to dinucleoside polyphosphates. Since VEGFR2 receptor is obviously capable to synthesise dinucleoside polyphosphates, these mediators may modulate the effects of VEGFR2 due to their proliferative effects in general.

\section{Conclusion}

In conclusion, these findings are of interest for several reasons:

1. The results demonstrate for the first time that VEGFR2 shows a yet unknown enzymatic activity

2. Dinucleoside polyphosphates are being synthesised enzymatically by VEGFR2.

3. Dinucleoside polyphosphates may modulate the proliferative effects of VEGFR2 by an autocrine mechanism.

Acknowledgements This study was supported by a grant of the German Research Foundation (DFG, Ja-972/11-1/2), a grant from the Federal Ministry of Education and Research (01GR080701/09), grant FP7-HEALTH-2009-2.4.5-2 to "SysKid" (grant agreement 241544), "Mascara" (grant agreement 278249) from the European Union and by the Peter und Traudl Engelhorn Stiftung. We thank B. Egbers and D. Jacobi for excellent technical assistance.

\section{References}

1. Wiedon A, Tolle M, Bastine J, Schuchardt M, Huang T, Jankowski V, Jankowski J, Zidek W, van der Giet M (2012) Uridine adenosine tetraphosphate (Up4A) is a strong inductor of smooth muscle cell migration via activation of the $\mathrm{P} 2 \mathrm{Y} 2$ receptor and crosscommunication to the PDGF receptor. Biochem Biophys Res Commun 417:1035-1040

2. Jankowski V, Guenthner T, Herget-Rosenthal S, Zidek W, Jankowski J (2009) Dinucleoside polyphosphates and uremia. Semin Dial 22:396-399

3. Jankowski V, van der Giet M, Mischak H, Morgan M, Zidek W, Jankowski J (2009) Dinucleoside polyphosphates: strong endogenous agonists of the purinergic system. Br J Pharmacol 157:1142-1153

4. Rapaport E, Zamecnik PC (1976) Presence of diadenosine 5',5" $\mathrm{P} 1, \mathrm{P} 4$-tetraphosphate $\left(\mathrm{Ap}_{4} \mathrm{~A}\right)$ in mamalian cells in levels varying widely with proliferative activity of the tissue: a possible positive "pleiotypic activator". Proc Natl Acad Sci USA 73:3984-3988

5. Flodgaard H, Klenow H (1982) Abundant amounts of diadenosine 5',5"'-P1, P4-tetraphosphate are present and releasable, but metabolically inactive, in human platelets. Biochem J 208:737-742

6. Lüthje J, Ogilvie A (1983) The presence of diadenosine $5^{\prime}, 5^{\prime \prime \prime}-\mathrm{P} 1$, P3-triphosphate (Ap3A) in human platelets. Biochem Biophys Res Commun 115:253-260

7. Jankowski J, Tepel M, van der Giet M, Tente IM, Henning L, Junker R, Zidek W, Schlüter H (1999) Identification and characterization of $\mathrm{P}_{1}, \mathrm{P}_{7}$-diadenosine-5'-heptaphosphate from human platelets. J Biol Chem 274:23926-23931

8. Schlüter H, Offers E, Brüggemann G, van der Giet M, Tepel M, Nordhoff E, Karas M, Spieker C, Witzel H, Zidek W (1994) Diadenosine phosphates and the physiological control of blood pressure. Nature 367:186-188

9. Yegutkin G, Jankowski J, Jalkanen S, Gunthner T, Zidek W, Jankowski V (2008) Dinucleotide polyphosphates contribute to purinergic signalling via inhibition of adenylate kinase activity. Biosci Rep 28:189-194

10. Yelovitch S, Camden J, Weisman GA, Fischer B (2012) Boranophosphate isoster controls P2Y-receptor subtype selectivity and metabolic stability of dinucleoside polyphosphate analogues. J Med Chem 55:437-448. doi:10.1021/jm2013198

11. Matsumoto T, Tostes RC, Webb RC (2012) Alterations in vasoconstrictor responses to the endothelium-derived contracting factor uridine adenosine tetraphosphate are region specific in DOCA-salt hypertensive rats. Pharmacol Res 65:81-90

12. Gui Y, He G, Walsh MP, Zheng XL (2011) Signaling mechanisms mediating uridine adenosine tetraphosphate-induced proliferation of human vascular smooth muscle cells. J Cardiovasc Pharmacol 58:654-662. doi:10.1097/FJC.0b013e318231e929

13. Jankowski V, Tölle M, Vanholder R, Schönfelder G, van der Giet M, Henning L, Schlüter H, Paul M, Zidek W, Jankowski J (2005) Identification of uridine adenosine tetraphosphate $\left(\mathrm{Up}_{4} \mathrm{~A}\right)$ as an endothelium-derived vasoconstrictive factor. Nat Med 11:223-227

14. Zhou Z, Merkus D, Cheng C, Duckers HJ, Jan Danser AH, Duncker DJ (2012) Uridine adenosine tetraphosphate is a novel vasodilator in the coronary microcirculation which acts through purinergic $\mathrm{P} 1$ but not $\mathrm{P} 2$ receptors. Pharmacol Res 67:10-17

15. Matsumoto T, Tostes RC, Webb RC (2011) The role of uridine adenosine tetraphosphate in the vascular system. Adv Pharmacol Sci. doi:10.1155/2011/435132 
16. Jankowski V, Vanholder R, van der Giet M, Tölle M, Karadogan S, Gobom J, Furkert J, Oksche A, Krause E, Tran TN et al (2007) Mass-spectrometric identification of a novel angiotensin peptide in human plasma. Arterioscler Thromb Vasc Biol 27:297-302

17. Gobom J, Schuerenberg M, Mueller M, Theiss D, Lehrach H, Nordhoff E (2001) Alpha-cyano-4-hydroxycinnamic acid affinity sample preparation. A protocol for MALDI-MS peptide analysis in proteomics. Anal Chem 73:434-438

18. Perkins DN, Pappin DJ, Creasy DM, Cottrell JS (1999) Probabilitybased protein identification by searching sequence databases using mass spectrometry data. Electrophoresis 20:3551-3567. doi:10.1002/(SICI)1522-2683(19991201)20:18<3551::AIDELPS3551>3.0.CO;2-2

19. Consortium TU (2011) Ongoing and future developments at the Universal Protein Resource. Nucleic Acids Res 39:D214-219

20. Larkin MA, Blackshields G, Brown NP, Chenna R, McGettigan PA, McWilliam H, Valentin F, Wallace IM, Wilm A, Lopez R et al (2007) Clustal W and Clustal X version 2.0. Bioinformatics 23:2947-2948

21. Lehmann K, Janda E, Pierreux CE, Rytomaa M, Schulze A, McMahon M, Hill CS, Beug H, Downward J (2000) Raf induces TGFbeta production while blocking its apoptotic but not invasive responses: a mechanism leading to increased malignancy in epithelial cells. Genes Dev 14:2610-2622

22. Tanaka K, Kawakami T, Tateishi K, Yashiroda H, Chiba T (2001) Control of IkappaBalpha proteolysis by the ubiquitin-proteasome pathway. Biochimie 83:351-356

23. Ma DJ, Li SJ, Wang LS, Dai J, Zhao SL, Zeng R (2009) Temporal and spatial profiling of nuclei-associated proteins upon TNF-alpha/ NF-kappaB signaling. Cell Res 19:651-664

24. Zhu S, Browning DD, White RE, Fulton D, Barman SA (2009) Mutation of protein kinase C phosphorylation site S1076 on alphasubunits affects $\mathrm{BK}(\mathrm{Ca})$ channel activity in HEK-293 cells. Am J Physiol Lung Cell Mol Physiol 297:L758-766

25. Roux PP, Ballif BA, Anjum R, Gygi SP, Blenis J (2004) Tumorpromoting phorbol esters and activated Ras inactivate the tuberous sclerosis tumor suppressor complex via p90 ribosomal S6 kinase. Proc Natl Acad Sci U S A 101:13489-13494. doi:10.1073/ pnas.0405659101
26. Liu L, Cao Y, Chen C, Zhang X, McNabola A, Wilkie D, Wilhelm S, Lynch M, Carter C (2006) Sorafenib blocks the RAF/MEK/ ERK pathway, inhibits tumor angiogenesis, and induces tumor cell apoptosis in hepatocellular carcinoma model PLC/PRF/5. Cancer Res 66:11851-11858

27. Zhang S, Cao Z, Tian H, Shen G, Ma Y, Xie H, Liu Y, Zhao C, Deng S, Yang Y et al (2011) SKLB1002, a novel potent inhibitor of VEGF receptor 2 signaling, inhibits angiogenesis and tumor growth in vivo. Clin Cancer Res 17:4439-4450

28. Spiekermann K, Faber F, Voswinckel R, Hiddemann W (2002) The protein tyrosine kinase inhibitor SU5614 inhibits VEGFinduced endothelial cell sprouting and induces growth arrest and apoptosis by inhibition of c-kit in AML cells. Exp Hematol 30:767-773

29. Dineen SP, Lynn KD, Holloway SE, Miller AF, Sullivan JP, Shames DS, Beck AW, Barnett CC, Fleming JB, Brekken RA (2008) Vascular endothelial growth factor receptor 2 mediates macrophage infiltration into orthotopic pancreatic tumors in mice. Cancer Res 68:4340-4346

30. Girling JE, Rogers PA (2009) Regulation of endometrial vascular remodelling: role of the vascular endothelial growth factor family and the angiopoietin-TIE signalling system. Reproduction 138:883-893

31. Sase H, Watabe T, Kawasaki K, Miyazono K, Miyazawa K (2009) VEGFR2-PLCgamma1 axis is essential for endothelial specification of VEGFR2+ vascular progenitor cells. J Cell Sci 122:3303-3311

32. Holmqvist K, Cross MJ, Rolny C, Hagerkvist R, Rahimi N, Matsumoto T, Claesson-Welsh L, Welsh M (2004) The adaptor protein shb binds to tyrosine 1175 in vascular endothelial growth factor (VEGF) receptor-2 and regulates VEGF-dependent cellular migration. J Biol Chem 279:22267-22275. doi:10.1074/ jbc.M312729200

33. Jankowski V, Meyer AA, Schlattmann P, Gui Y, Zheng XL, Stamcou I, Radtke K, Anh Tran TN, van der Giet M, Tölle M et al (2007) Increased Uridine Adenosine Tetraphosphate Concentrations in Plasma of Juvenile Hypertensives. Arterioscler Thromb Vasc Biol 27:1776-1781 